\title{
MAKNA SIMBOLIK TARI ASMARADANA KARYA PRAGINA GONG YOGYAKARTA
}

\author{
Nana Noviana \\ Fakultas Ilmu Pendidikan \\ Universitas Syiah Kuala Banda Aceh \\ Email nonanaviana@gmail.com
}

\begin{abstract}
Ringkasan
Tulisan ini bertujuan untuk mendeskripsikan makna simbolik tari Asmaradana karya Pragina Gong Yogyakarta. Pragina Gong adalah sebuah komunitas tari yang dibentuk sejak 3 Desember 2005 oleh mahasiswa Jurusan Tari Fakultas Seni Pertunjukan Institut Seni Indonesia Yogyakarta angkatan tahun 2004. Grup ini lahir dari peserta grand finaslis ajang pencarian bakat Indonesia's got Talent yang diadakan oleh salah satu stasiun TV swasta Indonesia.

Karya tari Praginagong berangkat dari unsur tradisional hingga kontemporer. Karya-karya tari yang diciptakan semua berangkat dari ide kreatif yang berpijak pada unsur tradisi, namun telah dikemas menjadi suatu sajian yang lebih inovatif dan bersifat entertainment (seni sebagai hiburan). Salah satu karya terbaiknya adalah tari Asmaradana.

Teori yang digunakan adalah teori semiotika dari Ferdinad de Saussure. Data yang digunakan dikumpulkan dengan teknik observasi non partisipan melalui melihat pertunjukan, mengamati anggota grup Pragina Gong berlatih serta dengan wawancara. Berdasarkan pengamatan tersebut dapat disimpulkan tari Asmaradana merupakan tari kreasi yang seringkali ditampilkan oleh grup pragina Gong. Tari tersebut selau dikembangkan sesuai dengan kebutuhannya. Konten dalam tari Asmaradana ini memiliki konsep yang menggambarkan tentang cinta kasih, keberagaman antar sesama manusia, bangsa dan tanah air yang diwujudkan dalam bentuk gerak, properti tari, iringan musik dan kostum.
\end{abstract}

Kata kunci: Asmaradana, Makna Simbolik, Pragina Gong 


\begin{abstract}
Abstrac
This paper aims to describe the symbolic meaning of Asmaradana dance by Yogyakarta Pragina Gong. Pragina Gong is a dance community that was formed on December 3, 2005 by students of the 2004 Indonesia Institute of the Arts- Yogyakarta Performing Arts Faculty Dance Department. This group was born from the grand finas participant of Indonesia's talent talent search event held by one of Indonesia's private TV stations.

Pragina Gong dance works depart from traditional to contemporary elements. The dance works created all depart from creative ideas that are based on traditional elements, but have been packaged into a more innovative and entertainment (art as entertainment) presentation. One of his best works is the Asmaradana dance.

The theory used is the theory of semiotics from Ferdinad de Saussure. The data used was collected using non-participant observation techniques through viewing the show, observing Pragina Gong group members practicing and interviewing. Based on these observations it can be concluded that Asmaradana dance is a creative dance that is often displayed by pragina Gong groups. The dance is always developed according to their needs. The content in the Asmaradana dance has a concept that describes love, diversity between people, nations and homeland which is manifested in the form of motion, dance property, musical accompaniment and costumes.
\end{abstract}

Keywords: Asmaradana, Symbolic Meaning, Pragina Gong

\section{PENDAHULUAN}

Sanggar seni merupakan jenis pendidikan non formal yaitu suatu tempat atau sarana yang digunakan oleh suatu komunitas tertentu atau sekelompok orang yang berkegiatan seni. Kegiatan yang ada di dalam sebuah sanggar seni berupa kegiatan pembelajaran tentang seni yang meliputi proses pembelajaran, penciptaan dan produksi.

Salah satu komunitas seni yang memiliki prestasi di Yogyakarta adalah Grup
Pragina Gong. Pragina Gong adalah sebuah komunitas tari yang anggotanya adalah alumni dan mahasiswa Institut Seni Indonesia Yogyakarta yang berdiri sejak 3 Desember 2005, dibentuk oleh mahasiswa Jurusan Tari angkatan tahun 2004. Nama Pragina Gong diambil dari arti kata, Pragina dalam bahasa Bali yang artinya adalah penari dan Gong adalah instrumen gamelan yang dimiliki hampir disetiap wilayah di Indonesia. Jadi Pragina Gong diartikan sebagai penari yang 
JOGED

ISSN: 1858-3989

mewakili berbagai suku dan budaya di Indonesia. Perkembangan anggota Pragina Gong saat ini tidak hanya dari jurusan Tari saja tetapi ada yang dari teater, musik dan seni rupa, dan dari kalangan umum. Karya tari Pragina Gong berangkat dari tradisional hingga kontemporer. Karya-karya tari yang diciptakan semua berangkat dari ide kreatif yang berpijak pada unsur tradisi, namun telah dikemas menjadi suatu sajian yang lebih inovatif dan bersifat entertainment (seni sebagai hiburan). Salah satu prestasi yang diraih oleh grup Pragina Gong adalah sebagai grand finaslis ajang pencarian bakat Indonesia's got Talent yang diadakan oleh salah satu stasiun TV swasta Indonesia yang membawakan tari Asmaradana.

Hasil karya tari adalah ekspresi manusia yang diwujudkan dalam bentuk simbol, bukan melambangkan sesuatu saja tetapi merupakan perwujudan ekspresi keseluruhan imajinasi kreatif seniman. Tari sebagai unsur kesenian tidak hanya dilihat sebagai hasil ciptaan, yaitu suatu benda, produk dari manusia, tetapi dalam hal ini lebih dipandang sebagai suatu simbol, lambang, yaitu mengartikan sesuatu tentang sesuatu, sehingga berkaitan dengan nilai, makna maupun pesan untuk diresapkan. Konteks isi sebagai tema-tema simbolik dalam tari atau koreografi, merupakan hasil simbolisasi seniman, maka prinsip penciptaan tari seperti itu merupakan pembentukan simbol dan pembentukan simbol bersifat abstraksi. Oleh karena itu konteks isi sebagai tema-tema simbolik tidak menunjuk pada bendanya tetapi lebih kepada konsepnya.

Pada penelitian ini, penulis melihat makna simbolik dari beberapa aspek yaitu kostum, properti tari, gerak, iringan musik dan pada konsep yang diwujudkan dalam karya. Tujuannya adalah menemukan simbol-simbol tertentu untuk mengartikan berbagai makna dalam tari Asmaradana tersebut.

\section{PEMBAHASAN}

\section{A. Kajian Teori}

Teori yang digunakan untuk mendasari dalam mengupas makna simbolik karya tari Asmaradana adalah teori semiotik. Dalam tari Asmaradana makna simbolik yang muncul tidak hanya yang terlihat secara tersurat atau langsung, tetapi juga tersirat dari setiap elemen tari.

Peneliti meminjam kacamata semiotik dari Ferdinand de Saussure dalam buku Semiotik dan Dinamika Sosial Budaya yang ditulis oleh Benny H. Hoed (2011) dengan istilah signifiant (penanda) dan signified (petanda) yaitu sesuatu yang hadir dalam kehidupan manusia dilihat sebagai tanda yang harus diberi makna. Ada empat hal yang mesti diperhatikan dalam semiotik, yaitu jenis tanda (ikon dan lambang), jenis sistem tanda 
(bahasa, musik, atau gerakan tubuh), jenis teks, dan jenis konteks atau situasi yang mempengaruhi makna tanda (kondisi psikologis, sosial, historis dan kultural).

Kacamata semiotik memungkinkan orang mengidentifikasi lebih terang gejala budaya dan sosial lewat tanda-tanda kehidupan yang menyertainya. Sementara "tanda" itu dipahami sebagai bentuk yang tercitrakan dalam kognisi manusia dan makna yang dipahami manusia. Pemikiran cenderung "struktural berbangun" itu diajukan Ferdinand de Saussure.

Pada penelitian ini, Hoed (2015) menjelaskan bahwa tanda sebagai bentuk dan makna isi yaitu tanda yang dipahami oleh manusia sebagai petanda. Dilihat dalam kehidupan sosial sebagai bentuk yang mempunyai makna tertentu. Dalam proses pemahaman makna tanda bukan sekedar karena ada proses oposisi (perbedaan), tetapi adanya proses penundaan. Hubungan antara penanda (bentuk tanda) dan petanda (makna tanda) untuk menemukan makna lain atau makna baru yang disebut proses dekonstruksi. Oleh karena itu, makna suatu tanda diperoleh sesuai dengan kehendak pemakai tanda.

Buku Sosiologi Tari yang ditulis oleh Sumandiyo Hadi (2005) memandang tari sebagai hasil kebudayaan yang sarat makna dan nilai disebut sebagai sistem simbol. Sistem simbol adalah sesuatu yang diciptakan oleh manusia yaitu suatu kerangka yang penuh dengan arti untuk mengorientasikan dirinya kepada yang lain. Pandangan sistem simbol lebih menunjukkan kepada konsep bukan pada artefak atau bendanya. Tari sebagai simbol dapat difahami sebagai sistem penandaan. Artinya, kehadiran tari tidak lepas dari beberapa aspek yang dapat dilihat secara terperinci, di antaranya yaitu gerak, iringan, tempat, pola lantai, waktu, tata pakaian, rias dan properti.

Buku Semiotika yang ditulis oleh Nur Sahid (2016) mengemukakan bahwa yang menghubungkan antara penanda dengan petanda adalah sistem tanda. Meskipun petanda atau makna dipahami Saussure sebagai konsep, realitas pikiran, tetapi pikiran itu sendiri baginya bukanlah substansi, sesuatu yang ada di dalam penanda. Saussure menempatkan makna sebagai bentuk, sebagai struktur, bukan substansi. Menurutnya semiotika merupakan ilmu yang ditujukan dalam pembelajaran makna dalam masyarakat yang bertautan dengan proses-proses signifikansi (penandaan) dan dengan prosesproses komunikasi, yakni sebuah alat atau media tempat makna-makna ditetapkan dan dipertukarkan. Saussure mengatakan bahwa ilmu tanda yang paling lengkap adalah bahasa. Susunan ilmu tanda tersebut dengan memberi dasar-dasar teori ilmu bahasa. Bahasa adalah simbol yang digunakan sehari-hari oleh 


\section{JOGED}

ISSN: $1858-3989$

manusia untuk berkomunikasi guna memahami gagasan yang tersirat atau amanat yang terdapat di dalamnya.

Pandangan Ferdinad de Saussure menganggap bahwa objek semiotika sebagai sistem tanda. Saussure menempatkan objek itu sebagai elemen-elemen tertentu yang saling berhubungan satu sama lain. Hubungan antar elemen itu disebut struktur. Menurut Saussure elemen-elemen sistem tanda tersebut terdiri dari dua struktur atau jenis hubungan yaitu hubungan sintagmatik dan hubungan paradigmatik. Hubungan sintagmatik adalah hubungan antar elemen yang hadir dalam tuturan, sedangkan paradigmatik antara elemen yang hadir dengan tak hadir atau semantik (Faruk, 1997). Bagi Saussure, hubungan struktural yang paling mendasar adalah oposisi antar elemen yang memungkinkan terbedakannya elemen yang satu dari elemen yang lain.

Buku Semiotika Visual yang ditulis oleh Kris Budiman (2011), menjelaskan bahwa penanda merupakan aspek material tanda yang bersifat sensoris atau dapat diindrai (sensible) yang berkaitan dengan sebuah konsep (petanda). Hakikat penanda adalah murni sebuah realatum yang pembatasannnya tidak mungkin terlepaskan dari petanda. Substansi penanda senantiasa bersifat material baik itu bunyi, objek, imaji dan sebagainya. Petanda merupakan aspek mental dari tanda-tanda yang biasa disebut juga sebagai konsep, yakni konsep-konsep ideasional yang tertanam di dalam imaji penuturnya. Artinya, petanda merupakan sebuah representasi mental dari apa yang diacu. Kedua elemen tanda ini menyatu dan saling ketergantungan satu sama lain meskipun penanda dan petanda dapat dibedakan tetapi pada praktiknya tidak dapat dipisahkan. Artinya, tiada penanda tanpa petanda, tiada petanda tanpa penanda. Kombinasi dari suatu konsep dan suatu citrabunyi inilah yang kemudian menghasilkan tanda.

\section{Buku Hand Book of Qualitative} Research yang ditulis oleh Denzin dan Lincold (2009) menjelaskan bahwa semiotika atau ilmu tanda mengandaikan serangkaian asumsi dan konsep yang memungkinkan kita untuk menganalisis sistem simbolik dengan cara sistematis. Tanda adalah sesuatu yang merepresentasikan atau menggambarkan sesuatu yang lain yaitu pemikiran sesorang terhadap tanda tersebut. Tanda terdiri dari dua materi dasar yaitu pertama ekspresi, seperti kata, suara atau simbol dan sebagainya. Kedua adalah konten atau isi, yakni makna atau arti. Proses penghubungan atau pemaknaan ekspresi dengan konten bersifat sosial dan sangat bergantung pada perspektif atau cara berfikir pengamat. Artinya suatu kontekslah yang dapat menghubungkan ekspresi dengan konten. Dalam kehidupan sosial, seluruh 
tindak komunikasi antar manusia sesungguhnya merupakan tanda.

\section{Menurut Blumer dalam Symbolic} Interaction Theory yang ditulis oleh Aksan menjelaskan bahwa manusia membentuk makna dengan dua cara yaitu (1) makna adalah sesuatu yang distribusikan kepada objek, peristiwa, fenomena dan sebagainya, (2) makna adalah pelengkap fisik yang ditetapkan oleh manusia terhadap peristiwa dan objek-objek. Menurutnya makna diciptakan manusia untuk menghasilkan beberapa fakta bagaimana manusia itu sendiri dalam membentuk makna.

\section{B. Metode Penelitian}

\section{Pengumpulan Data}

Pengumpulan data dari penelitian ini dilakukan dengan teknik non partisipant observation yaitu dengan melihat proses latihan tari Asmaradana di studio Grup Pragina Gong Yogyakarta. Penelitian ini juga dilaksanakan dengan teknik wawancara guna memperoleh hasil penelitian yang konkret.

Jenis wawancara yang digunakan oleh adalah wawancara semi terstruktur. Pada jenis wawancara ini, peneliti terlebih dahulu menyiapkan acuan wawancara atau protokol wawancara. Namun, saat pelaksanaannya, pertanyaan dapat bertambah disesuaikan dengan kebutuhan sehingga data yang diperoleh pun semakin beragam, tetapi hal ini wawancara masih dalam bahasan dan batasan penelitian.Wawancara semi terstruktur merupakan wawancara yang sama halnya dengan jenis pendekatan menggunakan wawancara petunjuk umum.

Peneliti melakukan wawancara dengan orang yang mempunyai hubungan terhadap rumusan masalah yang sedang diteliti, yaitu satu orang penata tari dan dua orang penari juga sekaligus merangkap penata tari Asmaradana di Grup Praginagong. Peneliti juga melakukan lanjutan wawancara dengan menggunakan android guna melengkapi data yang penulis butuhkan. Hasil informasi yang didapatkan dari informan atau narasumber didokumentasikan melalui media rekam suara dengan menggunakan android. Rekaman suara tersebut ditranskripsikan dan hasil transkripsi inilah yang selanjutnya digunakan sebagai coding sehingga menghasilkan temuan yang menjadi hasil penelitian.

\section{Pendekatan Penelitian}

Pendekatan yang digunakan dalam penelitian ini berjenis kualitatif Pendekatan kualitatif merupakan suatu pendekatan yang investigative karena peneliti di saat melaksanakan pengumpulan data diterapkan interaksi lansung di lapangan dengan orang atau objek yang bersangkutan yang menjadi narasumber penelitian. 


\section{Analisis Data}

Langkah awal yang dilakukan oleh peneliti adalah pada proses awal analisa, peneliti menentukan nara sumber yang dianggap ahli dan berkompeten untuk membantu menjawab pertanyaan penelitian. Setelah mendapatkan beberapa nara sumber yang dirasa tepat, selanjutnya peneliti melakukan proses wawancara.

Alat pendukung saat proses wawancara adalah media rekam audio, saat proses wawancara, peneliti juga menggunakan catatan khusus terkait list pertanyaan dan saat nara sumber menjawab pertanyaan yang peneliti tanyakan. Catatan khusus tersebut berupa gerak-gerik, istilah-istilah yang nara sumber sebutkan, dan ekspresi nara sumber saat merespons pertanyaan. Penulis merekam proses wawancara dengan menggunakan handphone yang sebelumnya penulis meminta izin terlebih dahulu kepada narasumber bahwa akan ada perekaman wawancara. Selanjutnya dalam melakukan wawancara tersebut peneliti sudah menentukan terlebih dahulu bentuk pertanyaan apa yang akan ditanyakan ke narasumbernya. Daftar pertanyaan tersebut berguna sebagai acuan atau panduan. Namun pada teknisnya pertanyaan dan bahasa yang digunakan pada saat wawancara tersebut tidak terlalu formal dan tertata dengan benar dalam bentuk pertanyaan karena juga ada pertanyaan- pertanyaan sederhana yang tidak penulis cantumkan didaftar pertanyaan.

Data yang diperoleh saat wawancara berupa data verbal, lalu data verbal tersebut dipindahkan ke dalam bentuk data teks. Data teks tersebut berupa transkripsi wawancara. Pada proses transkripsi wawancara, peneliti mengingat kembali saat proses wawancara dengan menandai bagian mana dari jawaban nara sumber yang diberi catatan-catatan khusus. Selanjutnya, setelah selesai melakukan transkripsi, peneliti kemudian melakukan pengkodingan.

Pengkodingan tersebut dilakukan guna memudahkan peneliti untuk menyaring data yang memungkinkan memiliki tujuan dan maksud yang sama. Dari data tersebut dapat diingat dengan mudah melalui pemberian label. Selanjutnya peneliti membuat memo. Memo tersebut merupakan ulasan tentang proses awal peneliti dalam melakukan penelitian. Dalam proses tersebut peneliti menentukan tahap-tahap untuk melakukan wawancara yang selanjutnya ditranskripsikan. Memo tersebut dapat berisi tentang kesulitan dan kemudahan peneliti dalam melakukan proses penelitian. Kemudian tahap selanjutnya peneliti melakukan pereduksian data yaitu dengan menyaring kembali dari pengkodingan sebelumnya sehingga mendapatkan jawabanjawaban dari pertanyaan penelitian. 


\section{Hasil Analisis}

Dalam penelitian ini, penulis melihat kajian makna simbolik dari beberapa aspek yaitu pada kostum, properti tari, gerak, iringan musik dan pada konsep yang diwujudkan dalam karya. Tujuannya adalah menemukan simbol-simbol tertentu untuk mengartikan berbagai makna dalam karya tari Asmaradana tersebut.

Temuan yang didapatkan yaitu sesuatu yang hadir dalam kehidupan manusia dilihat sebagai tanda yang harus diberi makna. Jadi memaknai suatu konsep tari itu dengan wujudnya yaitu karya. Hal ini seperti yang diungkapkan oleh pernyataan narasumber berikut:

. . . Sebenarnya kalau konsep tari Asmaradana itu lebih menceritakan ke perayaan. Jadi, selebrit tentang ke prajurit-prajurit. Di situ merayakan kemenangan, trus eee apa ya. kalau masalah duet, kan kalau tembangnya itu kan cinta kasih. Cinta kasih tentang cinta kasih. Tapi kalau di sini tu walaupun sebenarnya penarinya tu cewek cowok, eee tapi kita bukan mengibaratkan itu sepasang kekasih. Tapi kita lebih ke yaa kita ini prajurit yang cinta terhadap tanah air, ibu pertiwi, gitu. Makanya kenapa trus kita adain kayak topeng-topeng, trus eee apa lautan kek gitu. Jadi lebih ke cinta kasih ke yaa ibu pertiwi gitu, pokoknya ke apa prajurit-prajurit gitu. . . (Galih Suci Manganti, Sabtu 17 Maret 2018)

Begitu pula ungkapan hal yang sama diutarakan oleh narasumber lain yaitu:

. . . Eee kalau untuk makna keseluruhan itu mungkin ee tidak menceritakan sebuah tokoh menurut saya. Karya ini tidak menceritakan sebuah tokoh tapi kita cuman menyampaikan sebuah bentuk rasa cinta antara sebuah bentuk percintaan jatuh cintanya atau hubungan antara laki-laki dan perempuan. Eee yaaa sebenarnya eee intinya inti dari pengkaryaan ini adalah menyampaikan sebuah cerita percintaan tapi tidak menspesifikkan tokoh siapa. Seperti itu kalau menurut saya. . . (Rines Onixy Tampubolon, Senin 12 Maret 2018).

Untuk itu, berdasarkan hal di atas dapat dijelaskan dalam bentuk matrik yaitu matrik terbagi dalam kolom dan baris. Kolom yang berarti kasus dari makna simbolik tersebut. Sedangkan baris itu berarti aspek-aspek dalam makna simbolik tersebut yang saling berkesinambungan antara kolom dan baris.

\begin{tabular}{|c|c|c|}
\hline \multirow[b]{2}{*}{ Aspek } & \multicolumn{2}{|c|}{ Makna Simbolik } \\
\hline & $\begin{array}{c}\text { Penanda } \\
\text { (Signifier) }\end{array}$ & $\begin{array}{c}\text { Petanda } \\
\text { (Signified) }\end{array}$ \\
\hline Konsep & $\begin{array}{l}\text { Karya tari } \\
\text { Asmaradana }\end{array}$ & $\begin{array}{l}\text { - Kegembiraan } \\
\text { - ketegasan } \\
\text { - cinta kasih }\end{array}$ \\
\hline \multirow[t]{5}{*}{ Gerak } & $\begin{array}{l}\text { Gerak } \\
\text { teknik } \\
\text { liftingdan } \\
\text { Couple }\end{array}$ & $\begin{array}{l}\text { Penari putra } \\
\text { mengangkat } \\
\text { penari putri yang } \\
\text { menggambarkan } \\
\text { terjalinnya } \\
\text { hubungan yang } \\
\text { harmonis antara } \\
\text { sesama manusia } \\
\text { yang saling bahu } \\
\text { membahu. }\end{array}$ \\
\hline & Gerak silat & $\begin{array}{l}\text { Menggambarkan } \\
\text { kepahlawanan }\end{array}$ \\
\hline & $\begin{array}{l}\text { Gerak Cinta } \\
\text { kasih } \\
\text { berpasangan } \\
\text { dan } \\
\text { individu. }\end{array}$ & Kepedulian \\
\hline & $\begin{array}{l}\text { Gerak } \\
\text { Kekompaka } \\
\text { n }\end{array}$ & $\begin{array}{l}\text { Keberagaman dan } \\
\text { membahu }\end{array}$ \\
\hline & $\begin{array}{l}\text { Gerak } \\
\text { Ketegasan } \\
\text { penari laki- } \\
\text { laki dan } \\
\text { ketegasan }\end{array}$ & Kuat dan tangguh \\
\hline
\end{tabular}




\begin{tabular}{|c|c|c|}
\hline & $\begin{array}{l}\text { penari } \\
\text { perempuan }\end{array}$ & \\
\hline Ekpresi & $\begin{array}{l}\text { Wajah dan } \\
\text { tubuh }\end{array}$ & $\begin{array}{l}\text { - Ekspresi } \\
\text { perempuan } \\
\text { lembut dan } \\
\text { tegas } \\
\text { - Ekspresi laki- } \\
\text { laki tegas dan } \\
\text { kuat }\end{array}$ \\
\hline Kostum & $\begin{array}{l}\text { - Warna } \\
\text { merah } \\
\text { - Warna } \\
\text { emas/gol } \\
d\end{array}$ & $\begin{array}{l}\text { Modifikasi } \\
\text { kostum Jawa } \\
\text { Merah } \\
\text { menggambarkan } \\
\text { keberanian, } \\
\text { semangat dan } \\
\text { cinta kasih } \\
\text { Emas/Gold } \\
\text { menggambarkan } \\
\text { kerjasama, } \\
\text { kemuliaan dan } \\
\text { energi sosial. }\end{array}$ \\
\hline $\begin{array}{l}\text { Iringan } \\
\text { Musik }\end{array}$ & $\begin{array}{l}\text { Lagu } \\
\text { Asmaradana }\end{array}$ & $\begin{array}{ll}\text { - } & \text { Bernuansa } \\
\text { Jawa } \\
\text { - } \\
\text { Merayakan } \\
\text { kemenangan }\end{array}$ \\
\hline \multirow[t]{3}{*}{ Properti } & $\begin{array}{l}\text { Kain warna } \\
\text { putih }\end{array}$ & Kesucian \\
\hline & Topeng & Watak \\
\hline & $\begin{array}{l}\text { Kuku/tangg } \\
a i\end{array}$ & $\begin{array}{ll}\begin{array}{l}\text { Karakter } \\
\text { keindahan }\end{array} & \text { dan } \\
\end{array}$ \\
\hline \multirow[t]{2}{*}{ Penari } & Perempuan & Tegas dan lembut \\
\hline & Laki-laki & Tegas dan kuat \\
\hline
\end{tabular}

- Kolom terdiri dari makna simbolik yang terbagi dua yaitu:

1. Penanda (Signifier)

Penanda yaitu sebagai suatu bentuk suatu tanda

2. Petanda (Signified)

Petanda yaitu sebagai segi makna.

- Baris terdiri dari beberapa aspek yaitu:
Konsep tari. ide kreatif tari ini berangkat dari lagu yang memang sudah ada yaitu lagu dari Tiara Jacquelina. Lagu sound track nya putri gunung Ledang. Grup Pragina Gong tertarik dengan lagunya yang bernuansa Jawa dan ada tembangannya. Konsep tari Asmaradana lebih menceritakan ke perayaan. Keprajuritan dalam merayakan kemenangan dan cinta kasih tentang cinta kasih antar sesama, budaya dan tanah air.

Gerak. Tari Asmaradana menggambarkan tentang sosok prajurit yang kokoh dan menjadi seorang yang kuat dalam pertahanan. Pengembangan gerak yang bersemangat, keprajuritan, cinta kasih. Di antaranya adalah teknik gerak lifting yaitu teknik mengangkat dengan berpasangan atau couple. Gerak tersebut menggambarkan cinta kasih dan kebersamaan yang saling bahu membahu. Gerak kepahlawanan yaitu gerak yang menggambarkan tentang kepahlawanan, ada unsur pijakan silat dan ketegasan. Gerak cinta kasih berpasangan dan individu yaitu gerak ini menggambarkan sesama manusia yang memiliki kepedulian terhadap sesamanya baik itu dalam budaya dan negaranya. Gerak kekompakan yaitu gerak ini menggambarkan kebersamaan yang saling memberikan kepedulian sesamanya serta saling tolong menolong dalam berbangsa dan bernegara. Gerak ketegasan yaitu gerak ini 
menggambarkan sosok pribadi yang kuat dan tangguh.

Ekspresi. Dalam tari ini yaitu mencerminkan ketegasan dan kekuatan yang bertujuan untuk menekankan, menghidupkan, dan menguatkan suatu gagasan.

Kostum. Yang digunakan dalam tari ini dilihat dari bentuk kostum jawa yang dominan berwarna merah campur gold/emas. Warna merah menggambarkan sifat manusia yang diasosiasikan sebagai berani, kekuatan, kejantanan, cinta kasih dan bahagia. Warna emas/gold menunjukkan fenomena kehidupan manusia, memaknakan kemuliaan cinta yang mendalam dalam hubungan antar manusia.

Iringan. Musik yang digunakan adalah lagu Asmaradana yang sudah ada. Lagu Asmaradana dari Tiara Jacquelin, sound track nya putri gunung Ledang yang sudah di remix atau kolase. Lagu tersebut mencerminkan culture karena bernuansa Jawa, dan ada tembangannya. Berdasarkan konsep tarinya dengan musik tersebut lebih memperlihatkan sisi ke perayaan. Keprajuritan dalam merayakan kemenangan dan cinta kasih antar sesama, budaya dan tanah air.

Properti. Dalam tari Asmaradana digunakan tiga properti yaitu, kain warna putih dengan lebar delapan meter. Kain warna putih menggambarkan kesucian yang menunjukkan kesederhanaan dan kebersihan dalam kehidupan. Selain itu kain tersebut menggambarkan simbol samudra sebagai bentuk Indonesia adalah negri kepulauan. Topeng, Menggambarkan watak yang mencerminkan kebijaksanaan dan ketegasan. Selain itu topeng juga mewakili keberagaman Indonesia yang kaya akan suku, agama dan budaya. Kuku/tanggai. Melambangkan sebagai estetika yang menunjukkan karakter tari saja.

Penari. Ditarikan oleh perempuan dan laki-laki yaitu perempuan mencerminkan ketegasan dan keberanian namun tetap ada sisi kelembutan dari wanita. Sedangkan laki-laki yaitu mencerminkan sosok kejantaan, keberanian. Kepahlawanan, melindungi.

\section{III.PENUTUP}

Berdasarkan penelitian ini, dapat disimpulkan bahwa dalam proses guna mewujudkan simbol-simbol sangat diperlukan untuk mempermudah manusia dalam memahami hubungannya dengan wujud dari pembentukan sikap sosial melalui seni tari secara langsung mendidik pelakunya menuju proses penyadaran bahwa setiap individu terbentuk atas tiga dimensi yaitu manusia merupakan ciptaan Tuhan, manusia merupakan individu, serta manusia merupakan makhluk sosial. Sehingga dalam suatu penciptaan sebuah karya diperlukan adanya pendalaman makna dan simbol yang dapat 


\section{JOGED}

ISSN: $1858-3989$

mengartikan sebuah perwujudan karya tersebut.

Tari Asmaradana dapat disimpulkan memiliki konsep karya yang menggambarkan tentang cinta kasih, keberagaman antar sesama manusia, bangsa dan tanah air yang diwujudkan dalam bentuk gerak, properti tari, iringan musik dan kostum.

\section{DAFTAR SUMBER ACUAN}

\section{A. Sumber Tercetak}

Aksan, Nilgun. (2009). Symbolic Interaction Theory. Procedia Sosial and Behavioral Sciences. Vol 1: 902-904

Denzin dan Lincoln. 2009. Handbook of Qualitative Research. Yogyakarta: Pustaka Pelajar

Hadi, Sumandiyo. 2016. Koreografi BentukTeknik-Isi.Yogyakarta: Cipta Media

Hoed, Benny.H. 2011. Semiotik dan Dinamika Sosial Budaya. Jakarta: Komunitas Bambu

Budiman, Kris. 2011. Semiotika Visual Konsep, Isu dan Problem Ikonisitas. Yogyakarta: Jalasutra

Sahid, Nur. 2016. Semiotika untuk Teater, Tari, Wayang Purwa dan Film. Semarang; Gigih Pustaka Mandiri

B. Narasumber

Galih Suci Manganti, Sabtu, 17 Maret 2018 Koreografer Grup Pragina Gong Yogyakarta.
Rines Onixy Tampubolon, Senin, 12 Maret 2018 Mahasiswa Pasca Sarjana ISI Yogyakarta dan Penari Grup Pragina Gong.

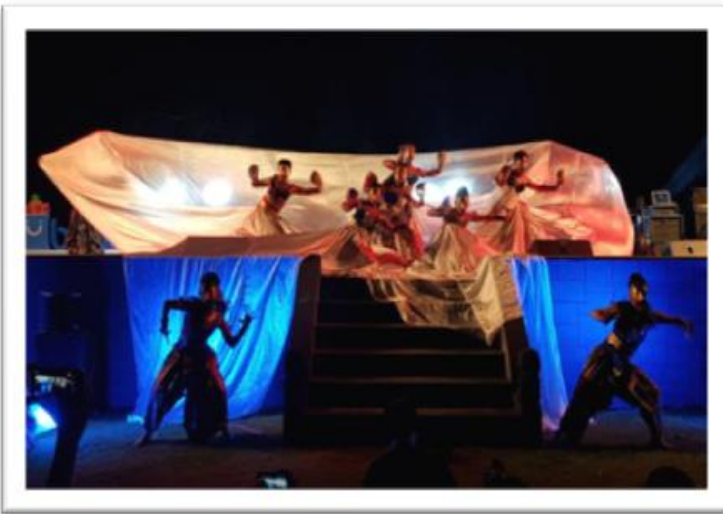

\section{Gambar 1}

Adegan penari menggunakan banyak topeng dan kain putih dengan ukuran besar untuk menggambarkan samudra Indonesia dan keberagaman dalam kesatuan yang ada di Indonesia.

Sumber Foto. Galih Suci Manganti 